\title{
COURSE PREPARATION ASSIGNMENTS: A TOOL TO ENHANCE INDEPENDENT LEARNING, INCREASE STUDENT PARTICIPATION, AND PERFORMANCE IN CHEMISTRY COURSES
}

\author{
Niina J. Ronkainen \\ Department of Chemistry and Biochemistry, Benedictine University, 5700 College Road, Lisle, IL \\ 60532-0900, USA, nronkainen@ben.edu
}

\begin{abstract}
Studies have shown that the more ownership students take of their academic work, the greater the level of information retained, knowledge acquired, and general cognitive development. Many teaching techniques that span across sciences, and go beyond standard techniques such as: merely lecturing at students or following written procedures for "cook book-style" laboratory experiments, have surfaced in the last decade. One such method, known as Course Preparation Assignments (CPAs), requires students to read and analyze course material prior to attending class. This approach gives students their first exposure to new content outside of the classroom, while also engaging them in responding to a series of questions that they must answer individually. This prior exposure to course material allows the students to not only complete written assignments with the incentive of earning points, but also forces them to reflect on what they are learning. Prior to adopting the CPA teaching practice, I discovered that very few of my chemistry and biochemistry students completed the reading and homework problems until a few days prior to an examination. Each class or unit that includes a CPA follows a predictable pattern which students adjust to quickly: Read - Think -Write/Draw/Calculate - Discuss the course content. The impact of incorporating CPAs into undergraduate Analytical Chemistry and Principles of Biochemistry lecture courses will be described from this instructor's point of view. In addition, the advantages and challenges of utilizing this teaching approach at a Primarily Undergraduate Institution, within classes made up of 8-45 students, will be described. Furthermore, the development and use of CPAs for teaching various Chemistry courses, the leading and facilitating of course discussions in class, the grading of assignments, and student perceptions of the approach will be discussed. Indeed, the pedagogical approach generally promotes timely completion of assignments, helps create a more interactive classroom setting, encourages students to ask more questions, facilitates involvement in discussions all of which result in an improved ability to think and reason critically.
\end{abstract}

Keywords Course Preparation Assignments, chemistry education, instructional pedagogies, studentcentered learning, interactive classroom environment, flipped classroom, Student Assessment of their Learning Gains

\section{Introduction}

Chemistry has a more quantitative focus than social sciences, biology, and many other disciplines. Therefore, many pedagogical approaches and classroom working practices utilized in other disciplines must be modified and customized to better suit the needs of chemistry instructors and their students. In addition, problem solving is an essential component of the physical sciences including chemistry. Also, chemistry courses continue to 
evolve over time with the course content and popular textbooks eventually more closely reflecting the concerns, research findings, technology, and sophistication of modern society. Meanwhile, some factors such as enthusiasm of the instructor for the subject matter being taught seem to be a universal and a critical component in teaching chemistry and other courses successfully (Sigga, 1970; Marsh, 1977; Marsh, 1980; Young \& Shaw, 1999; Patrick et al., 2000; Kunter et al., 2008). Instructor enthusiasm has been defined as the extent to which students perceive the instructor's ability to display enthusiasm, energy, humor, and to hold their interest (Marsh, 1980). In recent research on teacher behaviors, instructor's enthusiasm was found to be the most powerful unique predictor of students' intrinsic motivation and vitality in a course (Patrick et al., 2010).

Chemistry educators, especially at the introductory level, are often faced with the perception (by students) that chemistry is one of the most difficult subjects to learn. As a result, many students either opt out of taking chemistry courses or take only the courses required for the completion of their degree. Regardless, most chemistry educators are committed to providing high-quality instruction. In addition to professional development and instructional support, this typically involves the implementation of various pedagogical interventions and varied instructional techniques (Hofstein et al., 2006). Popular methods for improving student engagement, motivation, and learning outcomes in chemistry courses over the past fifteen years include: Digital game-based learning (Papastergiou, 2009), using Twitter (Junco et al., 2011), context-based case studies and context-based introduction of topics (Pringle, 1999; Gutwill-Wise, 2001; Bennett \& Homan, 2003; Belt et al., 2005; Potter \& Overton, 2006; Hofstein \& Kesner, 2006; Parchmann et al., 2006), service-learning (Kesner \& Eyring, 1999; Draper, 2004; Esson et al., 2005; LaRiviere et al., 2007; Kalivas, 2008; Sutheimer, 2008), problem-based learning (Ram, 1999; Belt et al., 2002; McDonnell et al., 2007; Gürses, 2007; Kelly \& Finlayson, 2007), process oriented guided inquiry learning, POGIL (Moog et al., 2008; Straumanis \& Simons, 2008; Bailey et al., 2008; Yezierski et al., 2008; Brown, 2010; Luxford et al., 2011; Hein, 2012), learning communities (Cross, 1998; McGregor et al., 2000; Dodge \& Kendall, 2004), collaborative learning (Kogut, 1997; Browne \& Blackburn, 1999; Kaartinen \& Kumpulainen, 2002; Shibley \& Zimmaro, 2002; Suthers \& Hundhausen, 2003) and the flipped classroom approach (Bergmann \& Sams 2012; Ruddick 2012; Smith 2013; Lancaster \& Read 2013; Christiansen 2014). Most of these methods have been guided by research on teaching and learning science, which over time, have affected current teaching practices and ultimately benefitted students.

The biggest hurdle in adopting any new instructional technique has to do with how confident teachers feel about using teaching approaches that are different from how they were taught. In addition, student evaluation scores, which play an important role in determining faculty promotions as well as rank and tenure, often decrease when new instructional methods, especially those that shift the focus from the instructor to the student, are introduced. Student-centered teaching style emphasizes student engagement in learning with less emphasis on "coverage" of concepts by the teacher through lecture or other student- 
passive means (Bunce 2011). This teaching approach appeals to many learning styles, generally includes multiple assessment measures, and is often cooperative. Decay of knowledge is generally expected to be less in courses where student mastery of concepts and student engagement are emphasized (Bunce 2011). It has also been suggested that instructional techniques should be matched closely with the learners' characteristics, learning styles, and interests in order to maximize the effectiveness of teaching and learning processes in addition to increasing students' motivation level (Hofstein \& Walberg, 1995). Motivation may be defined as the internal state that captures, directs, and sustains student behavior in achieving goals (Glynn 2007) or in connection with student's motivation to learn as student's tendency to find academic activities worthwhile (Bunce 2011). Teachers' working practices continue to evolve over time as students and society change.

A recently popular approach across various disciplines of flipped, (or inverted) classroom in its broadest sense may be thought of as having "events that have traditionally taken place inside the classroom now take place outside the classroom and vice versa” (Lage et al. 2000). However, despite the name and the simple definition, the flipped classroom teaching approach goes beyond merely re-ordering of classroom and at-home activities. The flipped classroom can also be thought of as "an educational technique that consists of two parts: interactive group learning activities inside the classroom, and direct (computer-based) individual instruction outside the classroom" (Bishop \& Verleger 2013). I will describe a recent instructional approach called Course Preparation Assignments (CPAs) which I have found to be effective in Analytical Chemistry and Biochemistry courses offered at a private, primarily undergraduate institution in the United States. The approach combines studentcentered teaching with more traditional methods of teaching chemistry such as problem solving and emphasizing critical thinking. This approach also includes aspects of flipped classroom teaching style. The video lectures outside of class that are often associated with flipped classroom are replaced by reading assignments from the textbook or journal articles followed by problem solving and critical thinking that are done by students individually prior to attending class.

\section{Course Preparation Assignments (CPAs)}

In the past, Course Preparation Assignments (CPAs) have mostly been used in teaching undergraduate social sciences and business (Yamane, 2006). However, since chemistry is a quantitative physical science where problem solving plays a key role, modifications had to be made to the idea of the CPA teaching tool as utilized by faculty in non-science disciplines. To my knowledge, I am the first to introduce this teaching approach to chemistry and biochemistry courses. The CPA approach seems particularly beneficial in chemistry subdisciplines that involve a significant amount of reading, such as Analytical Chemistry (including Instrumental Analysis, Quantitative Analysis, and Bioanalytical Chemistry \& Biosensors courses) and Biochemistry. 
Prior to adopting the CPA teaching practice, I discovered that very few of my chemistry and biochemistry students completed the reading and homework problems until a few days prior to an examination. As most instructors agree, repeated exposure to new material over longer periods of time and when presented in a logical progression, results in better learning outcomes. The working space, the conscious part of our mind used for information processing, is finite and most people are only able to process and store a limited amount of information in a given time (Johnstone, 2000). In order to store newly introduced information after accepting it, most people look for clear attachments in their long term memory on which to affix the new knowledge (Johnstone, 2000). If we try to learn too much information at once, learning may become faulty or will not take place at all (Johnstone, 2000). This is because the mind becomes overloaded and information processing shuts down. Therefore, studying primarily in the days leading up to an examination does not provide students with the learning outcome that will allow them succeed in a course or allow them to retain that information for cumulative final examinations or later discipline-specific standardized examinations. The CPA instructional technique facilitates the learning and retention of new information as it provides an additional, first exposure to the course material before it is even covered by the instructor and discussed in class.

As has been suggested before, lecturing to students may not be the most effective or time efficient way to cover course content (Bunce, 2011). Merely presenting the information to the students does not necessarily translate into students' understanding and learning the material. As visualized in the Cone of Learning, the more involved the students are in the learning process, the longer they seem to retain the information taught (Dale, 1969). For instance, most students remember $90 \%$ of what they say and do versus only $20 \%$ of what they only hear or $50 \%$ of what they hear and see (Dale, 1969). The nature of student involvement in instructional approaches, such as CPAs, is more active than in lectures, as it includes reading, thinking, and writing, discussing and explaining course content rather than the passive verbal or visual receiving that occurs during a traditional lecture. I believe the active nature of student involvement in learning by using CPAs, is the main reason for the increase in final examination scores and overall course grades that I have observed since incorporating CPA use into my teaching style. CPA approach in teaching will now be discussed in more detail.

The CPA approach is more student-centered than the traditional lecture-followed byhomework assignments completed by students outside of class. With the CPA approach, the ownership of learning is placed first and foremost on the students (Yamane, 2006). CPAs require students to read and analyze the course material prior to attending class, thereby giving the students their first exposure to new course content outside of the classroom (Yamane, 2006). Each class or unit that includes a CPA follows a predictable pattern that students adjust to very quickly: Read - Think -Write/Draw/Calculate - Discuss the course content. In my classroom, I include a detailed description of the CPAs, their purpose, and related course procedures in the course syllabus, and discuss it with each new group of 
students at the beginning of the semester. CPAs also offer additional practice problems which the instructor can place in an interesting and relevant context, while tailoring the difficulty level of the calculations to the abilities of each student group. The assignments are often designed in such a way that they may be quickly graded by the instructor or a Teaching Assistant based primarily on completion or attempt. Although it is more time consuming, points are taken off for incorrect answers to questions that can easily be answered based on the assigned reading. The ultimate objectives of the CPAs are to facilitate informed class discussions, to perform higher order reasoning, provide intellectual stimuli, use limited class time more effectively, and to respond to students' most commonly asked questions as a whole during class.

\subsection{Implementation of the CPAs in chemistry courses}

Regardless of the specific course, I typically assign CPAs for every new chapter/major topic. Students turn in one copy of the CPA at the beginning of class that will later be graded and keep a copy that will be amended during our class discussion. The assignments consist of reading assignments (from textbooks, handouts or journal articles) accompanied by informal writing assignments. Students are individually guided through the reading assignments by a series of questions that later serve as a basis for class interaction, example problems, and in class discussions. Questions, posted about a week in advance of the assignment deadline, vary in level of difficulty from providing a list, to defining a term, to indicating the most important idea, to examining the limitations of a method, to comparing and contrasting different methods, to solving word problems, to drawing diagrams, to applying chemical principles, and performing mathematical calculations. Selected examples of the types of questions I have used in the CPAs from various courses are included in the appendix.

\subsection{Classroom interaction and the role and responsibilities of the instructor}

The CPA approach forces the instructor to go beyond merely lecturing to the students and transition from instructor- to student-centered learning in a course. The use of CPAs generally creates a more discussion-based and interactive classroom environment where the input and opinions of the students are valued. Ideally, the CPA questions are discussed collectively as a class on the same day they are due which is also when students remember what they read and thought about while working on the assignment. However, sometimes the timing does not work out perfectly as the assignments are posted in advance and the discussion may happen during the next class period. The instructor's primary role during class is to facilitate discussions while going over sections of the CPA, ask related questions that may be more in-depth, and provide additional explanations, additional examples or clarification when required.

When I first started using the teaching approach, there were 5 or 6 CPAs in any given course during a 15 week semester. I wanted to try the approach with students to see if it would be effective in chemistry courses as all the previous reports related to CPAs had been 
from humanities or business faculty members. Nowadays, I may have as many as 10 CPAs in a 15 week semester which significantly increases the amount of time spent grading the assignments. Therefore, frequent use of CPAs is easier in courses that have fewer students and having a knowledgeable and dependable teaching assistant to help with grading the CPAs becomes necessary with the larger courses. In addition, planning and writing the CPAs and the corresponding answer keys can be time-consuming for the instructor. The assigned questions or calculations must also be modified or re-written from year to year because students may gain access to course materials through students who took the course in the past. Ideally, the assignments should be posted or distributed about 5-8 days before they are due in class to allow enough time for students to read and think about the questions prior to writing their responses. This requires a few weeks of planning ahead on the instructor's part. In addition, the instructor has to read the assignments in detail and work through the accompanying questions and problems because the questions which students ask during class are often in-depth and may be related to information only briefly touched upon in the reading assignment. In short, the instructor has to be well prepared for each class that uses the CPA approach. The instructor also has to be vigilante for and correct any student misconceptions as well as partially correct answers that may arise during class. For these reasons, the CPA teaching approach may be easier to adopt for instructors who already have a few years of experience teaching the course in which they plan to implement CPAs.

In my experience, the CPAs have resulted in more effective use of class time and have changed the way my students study for the course. Rather than waiting until few days before a quiz or an examination, most students keep up with the course material on a weekly basis. A few students even indicated that the CPA approach has influenced how they study for other courses. For example, one student stated that "The CPAs have made me become a much closer reader." Another student wrote: "It has helped me learn that studying a little bit all the time will help me keep caught up." Many students have also verbally expressed to me that they like the structure that the assignments have provided for the courses as each class that includes a CPA follows a predictable pattern: Read - Think - Write/Draw/Calculate Discuss the course content. Written student feedback was collected over four semesters using the Student Assessment of their Learning Gains (SALG) instrument.

The open-ended student responses below reflect their thoughts about changes in classroom interaction as a result of the CPAs. The students in Analytical Chemistry courses were asked in the SALG surveys: "Please comment on how the CPA activities have affected the classroom atmosphere and your participation during class."

\section{Sample Comments from Students}

"One of the good things about the CPA was the class discussion. When no one talks in class besides the instructor the class gets to be boring, so I think the CPA was a good way to keep us engaged and paying attention." 
"I participated every time. Sometimes I was wrong, but that was no big deal. That's the best way to correct something that is wrong."

"I participate often in class discussions. The atmosphere is very open and friendly and this helped me participate more in discussions more than I would in other courses. "

\subsection{Student assessment of the CPAs and their learning gains}

Second, third and fourth year university science students in Analytical Chemistry and Biochemistry courses that I teach regularly have adapted well to the use of CPAs. Feedback and student perception of the teaching approach was assessed using Student Assessment of their Learning Gains (SALG), a free instrument, now used by over 10,000 instructors and originally developed by Elaine Seymour in 1997 with support from the National Science Foundation (USA). The SALG instrument (available at http://www.salgsite.org/), which is easy to customize by the instructor and provides valuable statistical information as well as anonymous written responses, asks students to examine and report on their learning, and on the degree to which specific aspects of the course had an impact on that learning. As a result, regular collection and analysis of SALG survey data at the end of the semester has improved the effectiveness and use of CPAs in the courses I teach as well as in other aspects of the courses that are assessed by the survey that I designed such as course notes, the textbook, the Teaching Assistant, and examinations. The students' feedback has mostly been very positive. Also, the students have even requested that CPAs be used more often, which is something I have gradually been doing in a majority of the courses I teach.

The open-ended student responses below reflect their thoughts about the CPAs. These formative assessments were done at the end of each semester between 2013 and 2014. Although qualitative, the responses give some idea about the student satisfaction, effectiveness of the assignments, and perceived impact of CPAs on student learning. The students in Analytical Chemistry courses were asked in the SALG surveys: "Please comment on how the CPA activities helped your learning."

\section{Sample Comments from Students}

"I believe that the CPAs are very beneficial for learning material and give you the ability to better understand material that was later covered in class. They also offer insight into topics that there is not enough time to fully cover during class time. Overall, I think that the CPAs are beneficial learning tools for class and exam preparation and I wish more classes had them because I think that they really help."

"The CPA was an excellent tool in order to introduce new material, in order to get an understanding of what's to come in the next chapter/ topic, and a set of challenging but not difficult problems that we are going to be expected to know. It combines definitions, calculations, and many other questions that correlate with the topics. They helped with quizzes and always were a good reference tool to look back at apart from the lecture notes."

"They helped in that they made me stay up to date in the class. I was also able to understand the content in class more." 
"The more times students are forced to go over the material before the test, the better they'll do. CPAs and quizzes were efficient and fair ways to accomplish this. They weren't tedious, but were helpful."

"I learn by writing down information. Seeing the material, then working through understanding the material so that I could form it in my own words really helped me in the long run."

"The CPAs are great. I am interested in pursuing analytical chemistry now."

"Trying to read and learn the material on my own helped me retain it better."

"I found the CPAs to be beneficial overall to learning. I went into class having an idea of what we would be talking about. They also served as a good review for some sections because it was material seen in general chemistry. I also think the CPA assignments helped to better quiz and test scores."

Quantitative analysis courses are mostly based on practical hands-on methodology, but also include certain modern electroanalytical instrumental analysis methods such as amperometry and voltammetry. The instructor generally attempts to find a balance between modern and classical course material, theory and application, and method development versus providing students with detailed procedures in the lab. As stated earlier, problem solving is an essential component of these courses. Concepts such as experimental design, sampling, sample preparation, knowledge of capabilities and limitations of each measurement technique, data analysis, presentation of results, and validation of procedures are also included. However, there is limited time to cover the entire content as presented in the textbooks, therefore the instructor must utilize class time effectively by choosing the class content and lab experiments carefully. The use of CPAs has allowed me to use the limited class time more effectively because students are introduced to the topics and theory as part of their reading assignments before having a formal discussion in class. I also include quantitative and qualitative problems from other disciplines where analytical methods are commonly used such as agriculture, biology, cosmetics industry, clinical chemistry, forensics, food and beverage analysis, quality control, environmental science, and pharmaceutical industry which also serves to expose the student to applications of quantitative analysis concepts and methods in other science disciplines and industry.

A summary and ratings of student assessed learning gains related to the use of CPA in Quantitative Analysis course is provided below. This course is for students completing a degree in Chemistry, Chemistry Secondary Education or Clinical Lab Science. Under Class Activities category in a SALG instrument, the students were asked "How much did each of the following aspects of the course help your learning?" The anonymous ratings were provided by 15 student volunteers who completed the course in 2013 and 2014. A numerical rating scale from 1-5 was used to answer the questions. Response of $1=$ no help; $2=$ little help; $3=$ moderate help; $4=$ much help; and $5=$ great help. Mean responses, standard deviations, and modes for each question are included in the evaluation summary. 
Table 1. Summary of CPA assessment using SALG instrument in Quantitative Analysis courses Spring 2013 \& 2014

\begin{tabular}{|c|c|c|c|}
\hline $\begin{array}{l}\text { How much did each of the following help your } \\
\text { learning? }\end{array}$ & $\begin{array}{c}\text { Mean } \\
\text { response }\end{array}$ & St. Dev. & Mode \\
\hline 1. Attending class & 4.9 & 0.35 & 5 \\
\hline $\begin{array}{l}\text { 2. Getting first exposure to new course content outside of } \\
\text { the classroom as preparing for a CPA }\end{array}$ & 4.9 & 0.38 & 5 \\
\hline $\begin{array}{l}\text { 3. Reading the course material in order to complete CPA } \\
\text { questions }\end{array}$ & 4.5 & 0.99 & 5 \\
\hline 4. CPA motivating you to keep up with the course material & 4.4 & 0.79 & 5 \\
\hline 5. Participating in CPA discussions during class & 4.4 & 0.71 & 5 \\
\hline 6. Listening to CPA discussions during class & 4.4 & 0.76 & 5 \\
\hline 7. CPA increasing your participation during class & 4.1 & 0.79 & 4 \\
\hline 8. CPAs resulted in more discussion-based course & 4.7 & 0.49 & 5 \\
\hline 9. Working independently on the CPA & 4.4 & 0.92 & 5 \\
\hline 10. CPAs helping you better focus your studying efforts & 4.4 & 0.92 & 5 \\
\hline $\begin{array}{l}\text { 11. CPAs helping you become more engaged in the course } \\
\text { material }\end{array}$ & 4.9 & 0.38 & 5 \\
\hline $\begin{array}{l}\text { 12. Use of CPAs helping you better retain the course } \\
\text { content you learned }\end{array}$ & 4.4 & 1.1 & 5 \\
\hline $\begin{array}{l}\text { 13. CPAs have helped stimulate my interest in Analytical } \\
\text { Chemistry and related fields }\end{array}$ & 4.6 & 0.71 & 5 \\
\hline 14. CPAs improving your quiz and exam scores & 4.2 & 1.1 & 5 \\
\hline $\begin{array}{l}\text { 15. CPAs decreasing the number of questions you have } \\
\text { over the course material }\end{array}$ & 4.1 & 1.03 & 5 \\
\hline 16. Overall use of CPAs as a learning tool & 4.4 & 0.53 & 5 \\
\hline
\end{tabular}

The Instrumental Analysis course includes qualitative and quantitative characterization using modern instrumental techniques such as mass spectrometry, chemical separations, and spectroscopy. Until about the 1970 s classical chemical analysis typically involved the study and measurement of relatively small organic molecules (drugs, pesticides, industrial chemicals, radionuclides, explosive residues etc.) or metal ions. Much has changed since the 1970s, therefore textbook content and instructors strive to keep abreast of the continuous improvements in instrumentation capabilities as the technology becomes more sophisticated and automated. Most of the current instruments are modular, benchtop "boxes" that, after sample introduction, quickly generate useful data as either numbers, tables, spectra, or graphs. Given the more compact designs of newer instruments these days, most students most likely no longer observe individual instrument components which characterized older models during laboratory experiments. As the instruments and instrument operation culture have changed significantly, many faculty members have expressed concerns that our undergraduate students are becoming mere "book readers and button pushers". Therefore, many students find having to learn details such as instrument components, their specific functions, and instrument diagrams in lecture class somewhat tedious and boring. Indeed, 
Instrumental Analysis requires greater memorization of details than perhaps any other course related to analytical chemistry. However, I find that it is very important for students to read the textbook regularly, and sometimes before topics are covered in class, in order to develop a working knowledge of instrumentation. In fact, the CPAs force students to read their textbook more often. Some of the students in Instrumental Analysis did not enjoy the CPA pedagogical approach as much as students in other courses that I teach. However, this was also the first course where they were introduced to the CPAs. Despite this, their grades on the cumulative final exam as well as overall course grades improved since I started using CPAs in the course.

A summary and ratings of student assessed learning gains related to the use of CPA in Instrumental Analysis course are provided below. Of note, most students taking this course are completing a degree in Biochemistry \& Molecular Biology, Biology, Chemistry, Chemistry Secondary Education, Clinical Laboratory Science or Health Sciences. This course is also required for any students pursuing a minor in Chemistry. Under Class Activities category of SALG instrument, the students were asked "How much did each of the following aspects of the course help your learning?" The anonymous ratings were provided by 42 student volunteers who completed the course in 2013 and 2014. Mean responses, standard deviations, and modes for each question are included in the evaluation summary.

Table 2. Summary of CPA assessment using SALG instrument in Instrumental Analysis courses Fall 2013 \& 2014. A numerical rating scale from 1-5 was used to answer the questions.

\begin{tabular}{lccc}
\hline $\begin{array}{l}\text { How much did each of the following help your } \\
\text { learning? }\end{array}$ & $\begin{array}{c}\text { Mean } \\
\text { response }\end{array}$ & $\begin{array}{l}\text { St. } \\
\text { Dev. }\end{array}$ & Mode \\
\hline $\begin{array}{l}\text { 1. Attending class } \\
\begin{array}{l}\text { 2. Getting first exposure to new course content outside of the } \\
\text { classroom as preparing for a CPA }\end{array}\end{array}$ & 4.5 & 0.78 & 5 \\
$\begin{array}{l}\text { 3. Reading the course material in order to complete CPA } \\
\quad \text { questions }\end{array}$ & 4.1 & 0.91 & 5 \\
$\begin{array}{l}\text { 4. CPA motivating you to keep up with the course material } \\
\text { 5. Participating in CPA discussions during class }\end{array}$ & 4.1 & 1.1 & 5 \\
$\begin{array}{l}\text { 6. Listening to CPA discussions during class } \\
\text { 7. Completion of CPA increasing your participation during } \\
\text { class }\end{array}$ & 3.8 & 1.1 & 5 \\
$\begin{array}{l}\text { 8. CPAs resulted in more discussion-based course } \\
\text { 9. Working independently on the CPA }\end{array}$ & 3.1 & 1.4 & 5 \\
$\begin{array}{l}\text { 10. CPAs helping you better focus your studying efforts } \\
\text { 11. CPAs improving your quiz and exam scores }\end{array}$ & 3.6 & 0.79 & 5 \\
$\begin{array}{l}\text { 12. CPAs decreasing the number of questions you have over } \\
\text { the course material }\end{array}$ & 3.1 & 1.1 & 4 \\
13. Overall use of CPAs as a learning tool & 3.9 & 1.1 & 5 \\
\hline
\end{tabular}


The vast improvements and developments in the instrumental analysis methods during the recent decades has led to the rapid expansion of bioanalytical chemistry which in turn has led to major progress in proteomics and genomics. In addition to easy-to-use bench top instruments that allow computer controlled analysis of biological samples, there are also many inexpensive, commercially available test kits based on robust and clever assay designs. Bioanalytical chemistry is a rapidly evolving and highly interdisciplinary area of chemistry that provides interesting contexts for learning analytical chemistry. For example, it has applications in medicine, forensic science, pharmacy, engineering, industry, materials, national defense, nanotechnology etc. Since Bioanalytical chemistry is constantly evolving as a discipline and the course is not offered annually, the use of primary literature as reading material for the course rather than textbooks makes sense. As many students are not accustomed to reading primary literature when they take my course, the CPA approach helps them develop the ability to locate relevant information in the journal articles, ascertain the main purpose and novelty of the study, and to think critically about whether conclusions drawn by authors are supported by the data presented. As one student recently stated in a SALG survey:

"The CPAs helped my learning tremendously because without (it) I wouldn't be able to figure out the key ideas of papers, after a while it got easier to interpret the articles and it helped increase my analytical skills for the exams."

A summary and ratings of student assessed learning gains related to the use of CPA in Bioanalytical Chemistry and Biosensors course are provided below. Most students taking this course are Chemistry majors or choose the course as an upper level elective for completing a chemistry minor. The anonymous ratings by 5 volunteers were provided by students who took the course in 2014. Under Class Activities category of SALG instrument, the students were asked "How much did each of the following aspects of the course help your learning?” Mean responses, standard deviations, and modes for each question are included in the evaluation summary.

Table 3. Summary of CPA assessment using SALG instrument in Bioanalytical Chemistry \& Biosensors course Fall 2014. A numerical rating scale from 1-5 was used to answer the questions.

\begin{tabular}{lccc}
\hline How much did each of the following help your learning? & $\begin{array}{c}\text { Mean } \\
\text { response }\end{array}$ & $\begin{array}{l}\text { St. } \\
\text { Dev. }\end{array}$ & Mode \\
\hline 1. Attending class & 4.6 & 0.89 & 5 \\
2. Getting first exposure to new course content outside of the & 4.4 & 0.55 & 5 \\
classroom as preparing for a CPA & 4.2 & 0.45 & 4 \\
3. Reading the course material in order to complete CPA & & & 5 \\
questions & 4.2 & 0.84 & 5 \\
4. CPA motivating you to keep up with the course material & 4.2 & 0.84 & 5 \\
5. Participating in CPA discussions during class & 4.3 & 0.84 & 4 \\
6. Listening to CPA discussions during class & 4.4 & 0.55 & 5 \\
7. Completion of CPA increasing your participation during class & 4.8 & 0.45 & 4 \\
8. CPAs resulted in more discussion-based course & 4.2 & 0.45 & 4 \\
9. Working independently on the CPA & &
\end{tabular}




\begin{tabular}{|c|c|c|}
\hline 10. CPAs helping you better focus your studying efforts & 4.2 & 0.84 \\
\hline 11. CPAs improving your quiz and exam scores & 4.6 & 0.55 \\
\hline $\begin{array}{l}\text { 12. CPAs decreasing the number of questions you have over the } \\
\text { course material }\end{array}$ & 4.4 & 0.55 \\
\hline 13. Overall use of CPAs as a learning tool & 4.8 & 0.45 \\
\hline
\end{tabular}

Currently, I am utilizing the CPA pedagogical approach in teaching Principles of Biochemistry, a one semester survey course that has a significant amount of reading and requires memorization of certain terminology, definitions, structures, theories, and other content. I have included examples of CPA questions in the appendix for this paper from the previous semester. In addition, the SALG instrument for the course was recently completed and used for the first time. I am also in the process of developing more CPA questions and discussion topics for use in the course.

\section{Conclusions}

Course Preparation Assignments provide students with the first introduction to new course content before discussion in class. The students read the textbook on their own, think about a series of questions related to what has been read, and answer these questions in writing. In addition to providing the students with additional exposure and repetition of the material they are expected to learn, they become active participants in class and tend to become more reflective of what they are learning. Most students respond well to CPAs and enjoy the structured classes since CPAs follow a predictable pattern of Read - Think Write/Draw/Calculate - Discuss the content. Also, the instructor becomes more of a facilitator or a discussion leader during class time as the atmosphere is more interactive. Students ask more questions, participate in discussions more frequently, and develop improved thinking and reasoning skills. The CPA teaching approach appears suitable for various analytical chemistry courses and also improves student learning outcomes. In addition, the CPA teaching approach has not adversely affected my student evaluations, unlike POGIL which I had used in certain courses in the past. I am also utilizing the CPA pedagogical approach in teaching Principles of Biochemistry, a one semester course that has a significant amount of reading and requires memorization of certain key content. It has been well-received by the students and I have also observed an increase in cumulative final exam scores and course grades since its introduction in Biochemistry. Overall, it has been my experience that the CPA approach seems promising and effective in several subdisciplines of chemistry. However, its use often requires a significant time commitment from the instructor especially during the first few semesters of its implementation. The instructor must also get students to "buy into the idea" in order for the teaching method to generate optimum results. 


\section{References}

Astin, A. (1985) Achieving Educational Excellence, San Francisco, CA, Jossey-Bass, 133-616.

Bailey, C. P., Minderhout, V., \& Loertscher, J. (2012). Learning transferable skills in large lecture halls: Implementing a POGIL approach in biochemistry. Biochemistry and Molecular Biology Education, 40(1), 1-7.

Belt, S. T., Evans, E. H., McCreedy, T., Overton, T. L., \& Summerfield, S. (2002). A problem based learning approach to analytical and applied chemistry. University Chemistry Education, 6(2), 6572.

Belt, S. T., Leisvik, M. J., Hyde, A. J., \& Overton, T. L. (2005). Using a context-based approach to undergraduate chemistry teaching-a case study for introductory physical chemistry. Chemistry Education Research and Practice, 6(3), 166-179.

Bennett, J., \& Holman, J. (2003). Context-based approaches to the teaching of chemistry: What are they and what are their effects?.In Chemical education: Towards Research-based Practice (pp. 165-184). Springer Netherlands.

Bergmann, J. and Sams, A. Flip Your Classroom: Talk to Every Student in Every Class Every Day. International Society for Technology in Education, 2012. ISBN 9781564843159.

Bishop, J. L., \& Verleger, M. A. (2013). The flipped classroom: A survey of the research. In ASEE National Conference Proceedings, Atlanta, GA.

Brown, S. D. (2010). A process-oriented guided inquiry approach to teaching medicinal chemistry. American J ournal of Pharmaceutical Education, 74(7).

Browne, L. M., \& Blackburn, E. V. (1999). Teaching Introductory Organic Chemistry: A ProblemSolving and Collaborative-Learning Approach. J ournal of Chemical Education, 76(8), 1104-7.

Bunce, D. M. (2011). Investigating Classroom Myths Through Research on Teaching and Learning, first edition. American Chemical Society.

Christiansen, M. A. (2014). Inverted Teaching: Applying a New Pedagogy to a University Organic Chemistry Class. J ournal of Chemical Education, 91(11), 1845-1850.

Cross, K. P. (1998). Why learning communities? Why now. About Campus, 3(3), 4-11.

Dale, E. (1969) Audiovisual Methods in Teaching, third edition. New York: The Dryden Press;

Dodge, L., \& Kendall, M. E. (2004). Learning communities. College Teaching, 52(4), 150-155.

Draper, A. J. (2004). Integrating Project-Based Service-Learning into an Advanced Environmental Chemistry Course. J ournal of Chemical Education, 81(2), 221-224.

Esson, J. M., Stevens-Truss, R., \& Thomas, A. (2005). Service-Learning in Introductory Chemistry: Supplementing Chemistry Curriculum in Elementary Schools. J ournal of Chemical Education, 82(8), 1168-1173.

Glynn, S. M., Taasoobshirazi, G., \& Brickman, P. J. (2007). Nonscience majors learning science: a theoretical model of motivation. J ournal of Research in Science Teaching, 44(8), 1088-1107.

Gürses, A., Açıkyıldız, M., Doğar, Ç., \& Sözbilir, M. (2007). An investigation into the effectiveness of problem-based learning in a physical chemistry laboratory course. Research in Science \& Technological Education, 25(1), 99-113.

Gutwill-Wise, J. P. (2001). The Impact of Active and Context-based Learning in Introductory Chemistry Courses: An Early Evaluation of the Modular Approach. J ournal of Chemical Education, 78(5), 684-90.

Hein, S. M. (2012). Positive impacts using POGIL in organic chemistry. J ournal of Chemical Education, 89(7), 860-864.

Hofstein, A., \& Kesner, M. (2006). Industrial chemistry and school chemistry: Making chemistry studies more relevant. International J ournal of Science Education, 28(9), 1017-1039.

Hofstein, A., \& Walberg, H. J. (1995). Instructional strategies. Improving Science Education, 70-89.

Hofstein, A., Mamlok, R., \& Rosenberg, O. (2006). Varying instructional methods and assessment of students in high school chemistry. Assessment in Science, 139-148. 
Johnstone, A. H. (2000). Teaching of chemistry-logical or psychological?. Chemistry Education Research and Practice, 1(1), 9-15.

Junco, R., Heiberger, G., \& Loken, E. (2011). The effect of Twitter on college student engagement and grades. J ournal of Computer Assisted Learning, 27(2), 119-132.

Kaartinen, S., \& Kumpulainen, K. (2002). Collaborative inquiry and the construction of explanations in the learning of science. Learning and Instruction, 12(2), 189-212.

Kalivas, J. H. (2008). A Service-Learning Project Based on a Research Supportive Curriculum Format in the General Chemistry Laboratory. J ournal of Chemical Education, 85(10), 1410-1415.

Kelly, O. C., \& Finlayson, O. E. (2007). Providing solutions through problem-based learning for the undergraduate 1st year chemistry laboratory. Chemistry Education Research and Practice, 8(3), 347-361.

Kesner, L., \& Eyring, E. M. (1999). Service-Learning General Chemistry: Lead Paint Analyses. J ournal of Chemical Education, 76(7), 920-23.

Kogut, L. S. (1997). Using Cooperative Learning To Enhance Performance in General Chemistry. J ournal of Chemical Education, 74(6), 720-22.

Krajcik, J., \& Mamlok-Naaman, R. (2006). Using driving questions to motivate and sustain student interest in learning science. Teaching and learning science: An encyclopedia, 317-327.

Lage, M. J., Platt, G. J. \& Treglia, M. (2000). Inverting the classroom: A gateway to creating an inclusive learning environment. The J ournal of Economic Education, 31(1):30-43.

Lancaster, S. J., \& Read, D. (2013). Flipping lectures and inverting classrooms. Education in Chemistry, 50(5), 14-17.

LaRiviere, F. J., Miller, L. M., \& Millard, J. T. (2007). Showing the True Face of Chemistry in a Service-Learning Outreach Course. J ournal of Chemical Education, 84(10), 1636-1639.

Luxford, C. J., Crowder, M. W., \& Bretz, S. L. (2011). A Symmetry POGIL Activity for Inorganic Chemistry. J ournal of Chemical Education, 89(2), 211-214.

MacGregor, J., Tinto, V., \& Lindbald, J. H. (2000). Assessment of innovative efforts: Lessons from the learning community movement. Assessment to promote deep learning: Insight from AAHE's, 41-48.

Marsh, H. W. (1977). The validity of students' evaluations: Classroom evaluations of instructors independently nominated as best and worst teachers by graduating seniors. American Educational Research J ournal, 14(4), 441-447.

Marsh, H. W. (1980). The influence of student, course, and instructor characteristics in evaluations of university teaching. American Educational Research J ournal, 17(2), 219-237.

McDonnell, C., O’Connor, C., \& Seery, M. K. (2007). Developing practical chemistry skills by means of student-driven problem based learning mini-projects. Chemistry Education Research and Practice, 8(2), 130-139.

Moog, R. S., Creegan, F. J., Hanson, D. M., Spencer, J. N., Straumanis, A., Bunce, D. M., \& Wolfskill, T. (2008). POGIL: Process oriented guided inquiry learning (Vol. 2, pp. 90-107). Pearson Prentice Hall: Upper Saddle River, NJ.

Papastergiou, M. (2009). Digital game-based learning in high school computer science education: Impact on educational effectiveness and student motivation. Computers \& Education, 52(1), 1-12.

Parchmann, I., Gräsel, C., Baer, A., Nentwig, P., Demuth, R., \& Ralle, B. (2006). “Chemie im Kontext": A symbiotic implementation of a context-based teaching and learning approach. International J ournal of Science Education, 28(9), 1041-1062.

Patrick, B. C., Hisley, J., \& Kempler, T. (2000). “What's everybody so excited about?”: The effects of teacher enthusiasm on student intrinsic motivation and vitality. The J ournal of Experimental Education, 68(3), 217-236.

Potter, N. M., \& Overton, T. L. (2006). Chemistry in sport: context-based e-learning in chemistry. Chemistry Education Research and Practice, 7(3), 195-202.

Pringle, D. L. (1999). Effects of Context-Based Laboratory Experiments on Attitudes of Analytical Chemistry Students. J ournal of Chemical Education, 76, 100. 
Ram, P. (1999). Problem-Based Learning in Undergraduate Education. J ournal of Chemical Education, 76(8), 1122-26.

Ruddick, K. W. (2012). Improving chemical education from high school to college using a more hands-on approach.

Seymour, E. Wiese, D. Hunter, A. Daffinrud, S.M. (2000) Creating a Better Mousetrap: On-line Student Assessment of their Learning Gains. Paper presentation at the National Meeting of the American Chemical Society, San Francisco, CA, 1-40.

Shibley Jr, I. A., \& Zimmaro, D. M. (2002). The Influence of Collaborative Learning on Student Attitudes and Performance in an Introductory Chemistry Laboratory. J ournal of Chemical Education, 79(6), 745-48.

Smith, J. D. (2013). Student attitudes toward flipping the general chemistry classroom. Chemistry Education Research and Practice, 14(4), 607-614.

Straumanis, A., \& Simons, E. A. (2008). A multi-institutional assessment of the use of POGIL in Organic Chemistry. In ACS Symposium Series (Vol. 994, pp. 226-239). Oxford University Press.

Sutheimer, S. (2008). Strategies to Simplify Service-Learning Efforts in Chemistry. J ournal of Chemical Education, 85(2), 231-233.

Suthers, D. D., \& Hundhausen, C. D. (2003). An experimental study of the effects of representational guidance on collaborative learning processes. The J ournal of the Learning Sciences, 12(2), 183218.

Tomasek, T. (2009) Critical Reading: Using Reading Prompts to Promote Active Engagement with Text, International J ournal of Teaching and Learning in Higher Education, 21(1), 127-132.

Yamane, Y. (2006) Course Preparation Assignments: a Strategy for Creating Discussion-based Courses, Teaching Sociology, 34, 236-248.

Yezierski, E. J., Bauer, C. F., Hunnicutt, S. S., Hanson, D. M., Amaral, K. E., \& Schneider, J. P. (2008, September). POGIL implementation in large classes: Strategies for planning, teaching, and management. In Process oriented guided inquiry learning (POGIL), edited by: Moog, RS and Spencer, JN, ACS symposium series (Vol. 994, pp. 60-71).

Young, S., \& Shaw, D. G. (1999). Profiles of effective college and university teachers. J ournal of Higher Education, 670-686. 


\section{Appendix}

\section{Examples of CPA questions: Instrumental Analysis Course}

1. What are three ways in which molecules can interact with light?

2. Determining the level of phosphorus in urine is an important health indicator. Phosphate can be reacted with a molybdenum compound to form a colorful blue compound that absorbs at $690 \mathrm{~nm}$. A patient produced $1457 \mathrm{~mL}$ of urine in a day. A one $\mathrm{mL}$ aliquot of this urine was treated and diluted to $25.0 \mathrm{~mL}$. This colorful, diluted solution gave an absorbance reading of 0.555 . A standard cuvette with $1 \mathrm{~cm}$ pathlength was used. The molar absorptivity value is 4955 .

a) What is the molarity of phosphorus in the diluted sample?

b) What is the molarity of phosphorus in the urine (the original specimen)?

3. Draw a general design of a spectrofluorometer. Label all of the main components.

4. Draw the Lewis dot structure of water and name three vibrational modes for water molecules in molecular spectroscopy.

5. Why are the infrared absorption bands associated with $\mathrm{C}=\mathrm{O}$ bond stretching more prominent than many other peaks?

6. Why is it that glass or quartz prisms cannot be used as part of an interferometer and as sample holders in IR spectroscopy?

7. Define Doppler Effect as it applies to atomic spectroscopy.

8. What is a typical sample size in atomic spectroscopy when using a graphite furnace for the atomization step? How does that compare with sample required for flame atomic absorption spectroscopy?

9. What elements can be quantified by flame emission spectroscopy?

10. How can peaks that resulted from double ionization be identified on the mass spectrum?

11. What type of molecular ions are structurally the most stable?

12. What are the three major components of any chromatography system?

13. What parameter can be used to see whether a chromatographic peak is symmetrical?

\section{Examples of CPA questions: Quantitative Analysis Course}

1. If a $560 \mathrm{mg}$ sample to be analyzed using gravimetry is assumed to be pure $\mathrm{CaCl}_{2}$, how many milliliters of $0.1185 \mathrm{M}$ silver nitrate $\left(\mathrm{AgNO}_{3}\right)$ are required to precipitate it completely?

2. What gases are released during thermogravimetric analysis of calcium oxalate monohydrate?

3. What were some of the earliest chemicals manufactured during the Industrial Revolution?

4. Summarize in one sentence the effect of a titrant concentration on a titration curve when the titrant's concentration is decreased.

5. Potassium hydrogen iodate, $\mathrm{KH}\left(\mathrm{IO}_{3}\right)_{2} \mathrm{MW}=389.92 \mathrm{~g} / \mathrm{mol}$, is often used as a primary standard for the standardization of a $\mathrm{NaOH}$ base solution. If $0.4152 \mathrm{~g}$ of potassium 
hydrogen iodate is neutralized by $42.55 \mathrm{~mL}$ of a $\mathrm{NaOH}$ solution, what is the molar concentration of the $\mathrm{NaOH}$ solution?

6. Briefly describe documentation of the sampling location and points or patterns used to collect multiple primary samples of soil at a contaminated industrial site.

7. Balance the following redox reactions using the half-reaction method.

$$
\text { i. } \mathrm{Zn}+\mathrm{NO}_{3}{ }^{-} \rightarrow \mathrm{Zn}(\mathrm{OH})_{4}{ }^{2-}+\mathrm{NH}_{3} \text { (basic solution) }
$$

8. What is the purpose of a reference electrode in an electrochemical cell?

9. An electrochemical cell has a constant current of $285 \mu \mathrm{A}$ that is flowing through a wire for 645 seconds. What is the charge (in coulombs) that passed through the system?

10. Define junction potential.

11. Describe how using interdigitated array detection provides significant signal enhancements.

12. Describe the environmental impact of pharmaceutical pollution on humans, animals, and the society overall that were discussed in the assigned article.

13. List five biological specimens used in sample matrices for drug testing. What specimens provide the best correlation between current intoxication/impairment level and the concentration of the drug in the specimen collected and analyzed?

\section{Examples of CPA questions: Bioanalytical Chemistry and Biosensors Course}

1. What is the difference between biocatalytic sensors and affinity biosensors?

2. What are the roles of inner vs. outer membranes in enzyme electrodes?

3. Why are nanomaterials so commonly used in the design and fabrication of modern biosensors?

4. Define quantum dots.

5. Contrast monoclonal antibodies with polyclonal antibodies. How are antibodies produced?

6. Briefly describe ideal cancer biomarkers.

7. Compare and contrast voltammetry with amperometry.

8. Why are nanoelectrodes more suitable as transducers when measurements are made in live cells and organisms compared to normal macroelectrodes?

9. Why has the manufacturing of complex glass-based microfluidic chip devices usually been restricted to specialized labs or companies?

10. Why are modern mobile phones powerful tools and detectors especially for remote monitoring?

11. Why have the scientific community tried for years to replace the commonly used term "electronic nose"?

12. What was perceived as a major gap by the authors between the traditional "electronic nose" and classical analytical chemistry methods?

13. Briefly describe three applications of "electronic noses" in food and beverage industries.

14. Why is it sometimes beneficial to use disposable biosensors? 
15. What is glutamate? Why is it an important analyte in many biosensor applications?

16. Describe what information should be included in a well written abstract based on original scientific data for a poster or an oral presentation at a professional conference.

\section{Examples of CPA questions: Principles of Biochemistry}

1. Why do macromolecules have very little direct effect on cellular osmolarity per weight basis?

2. What are the three components found in all nucleotides?

3. What is the difference between saturated and unsaturated fatty acids?

4. What is the difference between an endothermic and an endergonic reaction?

5. Why is it important that ATP has an intermediate phosphoryl group transfer potential?

6. Define and describe solvation spheres.

7. Draw a titration curve for the titration of glutamine solution by $0.1 \mathrm{M} \mathrm{NaOH}$. Label important points on the curve.

8. What is the amino acid substitution in the hemoglobin of individuals who have Sickle

Cell trait or disease?

9. What holds together the chains of immunoglobulin G?

10. What protein denaturing treatment did Anfinsen use in his famous experiment?

11. Why are the relative orientations of nonpolar and polar amino acid side chains "insideout" in globular water-soluble proteins such as enzymes as compared to the amino acid side chain orientations in integral membrane proteins?

12. Why is enzyme regulation essential?

13. The polymer chains of glycosaminoglycans are widely spread apart and bind large amounts of water. What two functional groups of the polymer make this binding of water possible?

14. Name carbohydrates that have structural roles in the body rather than serving as energy sources.

15. Define the term reducing sugar.

16. Distinguish between catabolism and anabolism.

17. What is the main metabolic role of the liver? 